一技術報告一

ピレスロイド系農薬の薄層クロマトグラフィー, ガスクロマトグラフィー 質量分析法および液体クロマトグラフィ一質量分析法による一斉分析

地中 啓*1, 岩室嘉晃*1, 飯尾麗子*1, 高山成明*1, 角田紀子*2, 数井優子*3，太田彦人*3，大津留 修*3

石川県警察本部科学捜査研究所 $* 1$, 東京理科大学薬学部 $* 2$, 科学警察研究所*3

干920-8553 石川県金沢市鞍月 1-1*1

干278-8510 千葉県野田市山崎 $2641 * 2$

干277-0882 千葉県柏市柏の葉 6-3-1*3

\title{
Simultaneous Analysis of Pyrethroid Pesticides by Thin Layer Chromatography, Gas Chromatography/Mass Spectrometry and Liquid Chromatography/Mass Spectrometry
}

\author{
Satoshi Chinaka*1, Yoshiaki Iwamuro*1, Reiko Iio*1, Nariaki Takayama*1, \\ Noriko Tsunoda*2, Yuko Kazui*3, Hikoto Ohta*3 and Osamu Ohtsuru*3 \\ Forensic Science Laboratory, Ishikawa Prefectural Police H.Q. \\ 1-1 Kuratsuki, Kanazawa, Ishikawa 920-8553, Japan*1 \\ Faculty of Pharmaceutical Sciences, Tokyo University of Science \\ 2641 Yamazaki, Noda, Chiba 278-8510, Japan*2 \\ National Research Institute of Police Science \\ 6-3-1 Kashiwanoha, Kashiwa, Chiba 277-0882, Japan*3
}

(Received 25 January 2008; accepted 20 May 2008)

\begin{abstract}
Simultaneous analytical methods for 33 pyrethroids by thin layer chromatography (TLC), gas chromatography/mass spectrometry (GC/MS) and liquid chromatography/mass spectrometry (LC/MS) have been developed. The detection limits of the pyrethroids were $1 \mu \mathrm{g}$ or less by TLC, 10-100 pg by GC/MS (SIM mode) and 5-200 pg by LC/MS (SIM mode, except for transfluthrin ( $2 \mathrm{ng})$ ). The proposed methods were applicable to the analysis of the pyrethroids mixed into drinks and foods.
\end{abstract}

Key words: Pyrethroid, TLC, GC/MS, LC/MS

緒 言

ピレスロイド系農薬は家庭用や農業用の殺虫剂と

して広く普及している.多くのものが低毒性である
ことから中毒原因となることは少ないが，入手が容 易なことからいたずら等の目的で創食物に混入する 事案が散見される, 中でも, 家庭用殺虫剤として一 
般的なエアゾールタイプのものは, 噴射口を飲料等 の飲み口に差し込み, ボタンを押すだけで薬剤を容 易に混入できることから，これを使用した事案が比 較的多い。

ほとんどのピレスロイド系農薬は, シクロプロパ ン環とエステル結合を有するが，シクロプロパン環 がないものや，エステルではなくエーテル結合のも のもあり, その種類は数多い. ピレスロイド系農薬 の一斉分析法については, 残留農薬試験を目的とし た方法等が報告されているものの ${ }^{1-5)}$, 対象として いる化合物は多くても十数種類であり, 網羅的分析 を行っているものは見あたらない。 また, 微量成分 を対象としていることから, 検査試料の前処理も煩 雑である.そこで, 著者らは, 飲食物への混入事案 の様に, ある程度高濃度のピレスロイド系農薬が存 在する試料に適した迅速簡便な一斉分析法の確立を 目的として, 薄層クロマトグラフィー（TLC）, ガ スクロマトグラフィー質量分析法 (GC/MS) およ び液体クロマトグラフィー質量分析法（LC/MS） による分析法の開発を行った。

\section{1. 試薬類}

\section{材料および方法}

実験に用いたピレスロイド系農薬（合成ピレスロ イド27化合物，天然ピレスロイド 6 化合物）を Fig. 1 に示す。これらのうち, allethrin, bifenthrin, ethofenprox, fenpropathrin, fenvalerate, flucythrinate, permethrin, phenothrin, resmethrin, silafluofen, tefluthrinは関東化学製の, acrinathrin, cycloprothrin, cyfluthrin, cyhalothrin, cypermethrin, deltamethrin, fluvalinate, tralomethrin, transfluthrin $は$ 和 光純薬工業製の残留農薬試験用を用いた. 天然ピレ スロイドは 6 化合物の混合標準品（和光純薬工業 製，残留農薬試験用）を使用した。 それ以外のもの は殺虫剂メーカーより恵与されたものを用いた。各 化合物はアセトンに溶解し, $1 \mathrm{mg} / \mathrm{ml}$ 標準溶液とし た. 標準溶液は $-18^{\circ} \mathrm{C}$ で保管し, 用時アセトンで希

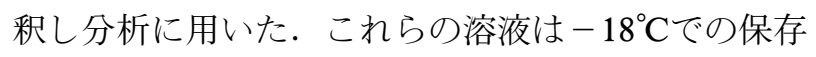
で，少なくとも 1 年間は安定であった。 なお，メタ ノールを溶媒とした場合に，CN 基をもつピレスロ イドの多くで分解が確認されたので, 注意が必要で
ある。

その他の試薬は市販の試薬特級品を用いた．超純 水は Millipore 製の Milli-RX12 $\alpha /$ Milli-Q SP シス テムにより製造した。

\section{TLC}

TLC 板は，Merck 製 Silicagel 60F254を用い，3 種類の展開溶媒を使用した。展開溶媒 $\mathrm{A}$ は, $n$-へ キサンートルエン $(45: 55, \mathrm{v} / \mathrm{v})$, 展開溶媒 B は, $n$-ヘキサンークロロホルム $(60: 40, \mathrm{v} / \mathrm{v})$, 展開溶 媒 C は， $n$-ヘキサンージエチルエーテル（50:50, $\mathrm{v} / \mathrm{v}$ ) である. スポットの検出は, 以下の 3 種類の 方法で行った。検出法 $\mathrm{a}: 254 \mathrm{~nm}$ のUV 照射によ り吸収を観察. 検出法 b : 20\%リンモリブデン酸/ エタノール溶液を噴霧後, $100^{\circ} \mathrm{C}$ で 5 分間加熱し発 色を観察. 検出法 c：0.5\%o-トリジン/エタノール 溶液を噴霧後, $254 \mathrm{~nm}$ の UV 照射を 5 分間行い発 色を観察.

\section{3. $\mathbf{G C} / \mathbf{M S}$}

装置は Agilent Technologies 製5973N GC / MSD を用い, カラムは Agilent Technologies 製 DB-5 ms （内径 $0.25 \mathrm{~mm}$, 長さ $30 \mathrm{~m}$, 膜厚 $0.25 \mu \mathrm{m}$ ) を使用し た. カラム温度は, 初期温度 $100^{\circ} \mathrm{C}$ で 1 分間保持し た後, $20^{\circ} \mathrm{C} /$ 分で $200^{\circ} \mathrm{C}$ ま昇温し, 引き続き $10^{\circ} \mathrm{C} /$ 分で $300^{\circ} \mathrm{C}$ な゙昇温した後, 5 分間保持した。 注入 口温度は $250^{\circ} \mathrm{C}$, トランスファーライン温度は 300 ${ }^{\circ} \mathrm{C}$, イオン源温度は $230^{\circ} \mathrm{C}$ と, キャリアガスとし て He $1.0 \mathrm{ml} /$ 分の定流量で用いた。試料注入量は $1 \mu \mathrm{l}$ とし, 注入はスプリットレスで行った. イオン 化法として電子衝撃イオン化法（イオン化電圧70 $\mathrm{eV})$ を用い, $m / z$ 50 550のフルスキャンモードで 測定した.

\section{LC/MS}

装置は Agilent Technologies 製 LC / MS 1100 SL を用い, カラムは化学物質評価研究機構製 Lcolumn ODS (内径 $2 \mathrm{~mm}$, 長さ $150 \mathrm{~mm}$, 粒径 3 $\mu \mathrm{m})$ をカラム温度 $40^{\circ} \mathrm{C}$ で使用した。移動相は 10 $\mathrm{mM}$ 酢酸アンモニウム（pH 5.0）とアセトニトリ ルの混合液を用い, アセトニトリル濃度が25分間で $40 \%$ から $100 \%$ となるリニアグラジェント条件と し, さらにアセトニトリル濃度 $100 \%$ で 5 分間保持 した. 試料注入量は $1 \mu \mathrm{l}$ とした. イオン化法はエ 


\section{Synthetic pyrethroids}

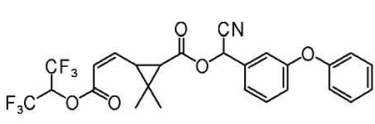

(1) acrinathrin<smiles></smiles>

(5) cyfluthrin<smiles>CC(C)(C)C(C=C(Br)Br)C(=O)OC(C#N)c1cccc(Oc2ccccc2)c1</smiles>

(9) deltamethrin

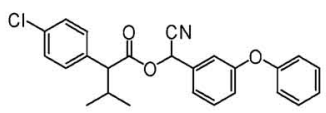

(13) fenvalerate<smiles>C=CCN1CC(=O)N(COC(=O)C(C=C(C)C)C(C)(C)C)C1=O</smiles>

(17) imiprothrin<smiles>C=CCC1C(=O)CC(OC(=O)C(C)(C)C)C1C</smiles>

(21) prallethrin<smiles>CC(C)=CC(C)(C)C(=O)ON1C(=O)C2CCCCC2C1=O</smiles>

(25) tetramethrin<smiles>C=CCC1C(=O)CC(OC(=O)C(C=C(C)C)C(C)(C)C)C1C</smiles>

(2) allethrin<smiles>Cc1c(COC(=O)C2C(C=C(Cl)C(F)(F)F)C2(C)C)cccc1-c1ccccc1</smiles>

(3) bifenthrin

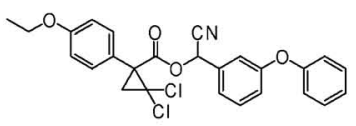

(4) cycloprothrin<smiles>CC(OC(=O)C1(C)CC1(C)CC(F)(F)F)c1cccc(Oc2ccccc2)c1</smiles>

(6) cyhalothrin

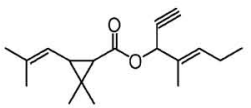

(10) empenthrin<smiles>CC(OC(=O)C1(C)C(=O)C=C(Cl)C1(C)C)c1cccc(Oc2ccccc2)c1</smiles>

(7) cypermethrin<smiles>CCOc1ccc(C(C)(C)COCc2cccc(Oc3ccccc3)c2)cc1</smiles>

(11) ethofenprox<smiles>CC(C)=CC(C(=O)OC(C#N)c1cccc(Oc2ccccc2)c1)C(C)(C)C</smiles>

(8) cyphenothrin<smiles>CC(C)C(C)C(C(=O)Oc1cccc(Oc2ccccc2)c1)C(C)C</smiles>

(14) flucythrinate<smiles>C/C=C/C1C(COC(=O)COC2=C(F)C(F)=C(COC)C2F)C1(C)C</smiles>

(18) metofluthrin<smiles></smiles>

(22) resmethrin<smiles></smiles>

(26) tralomethrin<smiles>CC(C)C(Nc1ccc(C(F)(F)F)cc1Cl)C(=O)OC(C#N)c1cccc(Oc2ccccc2)c1</smiles>

(15) fluvalinate<smiles>CC(C)(C)C(C=C(Cl)Cl)C(=O)OCc1cccc(Oc2ccccc2)c1</smiles>

(19) permethrin<smiles>CCOc1ccc([Si](C)(C)CCCc2ccc(F)c(Oc3ccccc3F)c2)cc1</smiles>

(23) silafluofen<smiles>CC(C)(C)C(C=C(Cl)Cl)C(=O)OCc1c(F)ccc(F)c1F</smiles>

(27) transfluthrin

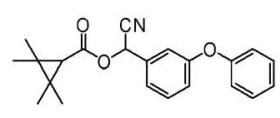

(12) fenpropathrin<smiles>C=CCc1ccc(COC(=O)C(C)(C)C=C(C)C)o1</smiles>

(16) furamethrin<smiles>CC(C)=CC(C)(C)C(=O)OCc1cccc(Oc2ccccc2)c1</smiles>

(20) phenothrin<smiles>Cc1c(F)c(F)c(OCC(=O)C(C)(C)C=C(Cl)C(F)(F)F)c(F)c1F</smiles>

(24) tefluthrin

\section{Natural pyrethrins}<smiles>CC=CCC1=C(C)C(OC(=O)C(C)(C)C)CC1=O</smiles>

(28) cinerin I<smiles>C/C=C/CC1C(=O)CC(OC(O)C(C=C(C)C(=O)OC)C(C)(C)C)C1C</smiles>

(31) cinerin II<smiles>CC/C=C/CC1=C(C)C(OC(=O)C(C)(C)C(C)(C)C)CC1=O</smiles>

(29) jasmolin I<smiles>CC/C=C/CC1C(=O)CC(OC(=O)C(/C=C(\C)C(=O)OC)C(C)(C)C)C1C</smiles>

(32) jasmolin II<smiles>C=CC=CCC1=C(C)C(OC(=O)C(C)(C)C(C)(C)C)CC1=O</smiles>

(30) pyrethrin I<smiles>C=CC=CC1C(=O)CC(OC(=O)C(C)(C)C)C1CC=C(C)C(=O)OC</smiles>

(33) pyrethrin II

Fig. 1 Thirty-three pyrethroids used in the present study. 
レクトロスプレーイオン化法（ポジティブ）とし， 乾燥ガスには $\mathrm{N}_{2}$ を $101 /$ 分, $300^{\circ} \mathrm{C} て ゙$ 用い, ネブラ イジングガスには $\mathrm{N}_{2}$ を $20 \mathrm{psi}$ で用いた。キャピラ リー電圧は $3000 \mathrm{~V}$ ，フラグメンター電圧は $60 \mathrm{~V}$ と し, $m / z 50 \sim 800$ のフルスキャンモードで測定し た。

\section{5. 検査試料および前処理}

飲食物への混入事案を想定して, 緑茶飲料, オレ ンジジュース，コーラおよびコーヒーの 4 種類の市 販飲料各 $5 \mathrm{ml}$ とレトルトカレー $5 \mathrm{~g}$ に，エアゾー ルタイプの市販殺虫剂 $0.1 \mathrm{ml}$ を添加したものを検査 試料とした。これは， $200 \mathrm{ml}$ あるいは $200 \mathrm{~g}$ の飲食 物に殺虫剂を数秒程度噴射した場合に相当する.

検査試料約 $1 \sim 5 \mathrm{~g}$ を $n$-ヘキサン $1 \sim 10 \mathrm{ml}$ で抽出 し, 得られた抽出液を無水硫酸ナトリウムで脱水 後, 孔サイズ0.45 $\mu \mathrm{m}$ のメンブランフィルターでろ 過し, 減圧下で $0.1 \sim 1 \mathrm{ml}$ 程度に濃縮し TLC 用並 びに GC/MS 用の測定試料とした。この一部につ いて, $\mathrm{N}_{2}$ 気流下で乾固後, 等量のアセトンに再溶 解し LC/MS 用の測定試料とした.

\section{結果および考察}

\section{TLC 分析法の検討および結果}

シリカゲルプレートを用い分離を試みた。展開溶 媒として各種溶媒について検討した結果，「材料㧈 よび方法」項に示す 3 種類の展開溶媒 $\mathrm{A}, \mathrm{B}, \mathrm{C}$ で 分離が良好であった．各化合物の Rf 值を Table 1 に示す．Rf 值が 2 つるものは，異性体が分離し たものである．なお，天然ピレスロイド 6 種混合物 については完全分離できず，展開溶媒 $\mathrm{C}$ により 3 種類ずつに分離するにとどまった。

検出については，蛍光剂入りのプレートを用いる ことで，全ての化合物について $254 \mathrm{~nm} の U V$ 照射 によりスポットの確認が可能であった，発色試液に よる検出では，リンモリブデン酸溶液を用いる方 法6)とo-トリジン溶液を用いる方法7)の両方を用い ることで，全ての化合物の検出が可能であった．各 化合物 $1 \mu \mathrm{g}$ をスポットした場合の検出結果を Table 1 に示す.

TLC では, 3 種類の展開溶媒と 3 種類の検出法 を組み合わせることにより， cyfluthrin と cyper- methrin, furamethrin と resmethrin を除くほとんど の化合物を分離識別することができた.

\section{GC/MS分析法の検討および結果}

GC/MS 分析条件について，一般的な微極性キャ ピラリーカラムを用いて検討を行い，良好な分離の 一斉分析条件を得た。合成ピレスロイド各 $10 \mathrm{ng}$ と 6 種混合の天然ピレスロイド100 ng を分析したトー タルイオンクロマトグラム（TIC）を Fig. 2 に，保 持指標を Table 2 に，マススペクトルをFig. 3 に示 す。なお， cycloprothrinについては検出感度が低 く，また， tralomethrinについては注入時にdeltamethrin に変化するため8), 分析対象から外し た．すなわち，33種のピレスロイド系農薬のうち， 31 の化合物の検出が本法により可能であった。 ま た，本法では多くのピレスロイドでその異性体同士 が分離し，TIC 上にて複数のピークとして検出さ れた。なお， pyrethrin I と pyrethrin II でピークの 拡がりが生じたが，これは熱による異性化のためと 考えられる ${ }^{9)}$. 各化合物の検出下限はフルスキャン モードで $0.1 \sim 1 \mathrm{ng}$, 選択イオンモニタリング （SIM）モードで0.01〜0.1 ngであった.

\section{LC/MS 分析法の検討および結果}

一般的な ODS カラムを用い, LC/MS 分析条件 の検討を行った。グラジエント条件を用いること で，30分以内に全化合物を溶出させることができ， 33化合物全ての一斉分析が可能であった。 エレクト ロスプレーイオン化の極性については，33化合物の うち 31 化合物でネガティブモードよりポジティブ モードの方が高感度もしくは同等であったことから ポジティブモードとした. Fig. 4 に合成ピレスロイ ド各36 ng と 6 種混合の天然ピレスロイド $100 \mathrm{ng} の$ 混合標準品を分析したマスクロマトグラムを示す。 $\mathrm{GC} / \mathrm{MS}$ と同様，複数のピークが存在するものは異 性体が分離検出されたものである。ママススペクトル のベースピークは, silafluofen を除き, $[\mathrm{M}+\mathrm{H}]^{+}$ または $\left[\mathrm{M}+\mathrm{NH}_{4}\right]^{+}$であり（silafluofen はべース ピークが $m / z 287 て ゙, ~\left[\mathrm{M}+\mathrm{NH}_{4}\right]+$ は 2 番目に大き なピーク), 全ての化合物で指標となる $[\mathrm{M}+\mathrm{H}]^{+}$ または $\left[\mathrm{M}+\mathrm{NH}_{4}\right]^{+}$の $m / z$ が異なっていた。した がって，LCでの分離は必ずしも充分とは言えない が，マスクロマトグラフィーにより，全化合物を一 
Table 1 Rf values and coloring results of TLC.

\begin{tabular}{|c|c|c|c|c|c|c|c|}
\hline \multirow{2}{*}{ No. } & \multirow{2}{*}{ Compound } & \multicolumn{3}{|c|}{ Developing solvent } & \multicolumn{3}{|c|}{ Chromogenic reagent } \\
\hline & & A & B & $\mathrm{C}$ & $\mathrm{a}$ & $\mathrm{b}$ & $\mathrm{c}$ \\
\hline (1) & acrinathrin & 0.18 & 0.34 & 0.6 & + & - & yellowish green \\
\hline (2) & allethrin & 0 & 0.07 & 0.5 & + & bluish gray & yellowish green \\
\hline (3) & bifenthrin & 0.51 & 0.56 & 0.65 & + & bluish gray & yellowish green \\
\hline (4) & cycloprothrin & 0.07 & 0.23 & 0.5 & + & - & yellowish green \\
\hline (5) & cyfluthrin & $0.19,0.25$ & $0.30,0.34$ & 0.6 & + & - & yellowish green \\
\hline (6) & cyhalothrin & 0.29 & 0.37 & 0.6 & + & - & yellowish green \\
\hline (7) & cypermethrin & $0.20,0.25$ & $0.30,0.34$ & 0.61 & + & - & yellowish green \\
\hline (8) & cyphenothrin & 0.18 & 0.3 & 0.6 & + & bluish gray & yellowish green \\
\hline (9) & deltamethrin & 0.25 & 0.33 & 0.59 & + & \pm & green \\
\hline (10) & empenthrin & 0.38 & 0.46 & 0.66 & + & bluish gray & - \\
\hline (11) & ethofenprox & 0.15 & 0.31 & 0.62 & + & bluish gray & - \\
\hline (12) & fenpropathrin & 0.21 & 0.32 & 0.63 & + & \pm & yellowish green \\
\hline (13) & fenvalerate & 0.22 & 0.32 & 0.61 & + & \pm & green \\
\hline (14) & flucythrinate & 0.15 & 0.27 & 0.56 & + & \pm & green \\
\hline (15) & fluvalinate & $0.10,0.20$ & $0.22,0.27$ & 0.57 & + & \pm & green \\
\hline (16) & furamethrin & 0.23 & 0.34 & 0.64 & + & bluish gray & - \\
\hline (17) & imiprothrin & 0 & 0 & 0.13 & + & bluish gray & - \\
\hline (18) & metofluthrin & 0.1 & 0.18 & 0.62 & + & bluish gray & yellowish green \\
\hline (19) & permethrin & $0.28,0.41$ & $0.36,0.43$ & 0.65 & + & \pm & green \\
\hline (20) & phenothrin & 0.22 & 0.35 & 0.65 & + & bluish gray & \pm \\
\hline (21) & prallethrin & 0 & 0.05 & 0.48 & + & bluish gray & yellowish green \\
\hline$(22)$ & resmethrin & 0.21 & 0.34 & 0.65 & + & bluish gray & - \\
\hline (23) & silafluofen & 0.5 & 0.49 & 0.65 & + & pink & - \\
\hline (24) & tefluthrin & 0.62 & 0.54 & 0.68 & + & - & yellowish green \\
\hline$(25)$ & tetramethrin & 0 & 0.06 & 0.42 & + & bluish gray & - \\
\hline (26) & tralomethrin & $0.20,0.28$ & $0.28,0.33$ & 0.57 & + & \pm & yellowish green \\
\hline$(27)$ & transfluthrin & 0.49 & 0.46 & 0.67 & + & \pm & yellowish green \\
\hline (28) & cinerin $\mathrm{I}$ & \multirow{6}{*}{$0-0.1$} & \multirow{6}{*}{$0-0.1$} & & & & \\
\hline (29) & jasmolin I & & & 0.53 & + & bluish gray & green \\
\hline$(30)$ & pyrethrin I & & & & & & \\
\hline (31) & cinerin II & & & & & & \\
\hline$(32)$ & jasmolin II & & & 0.38 & + & bluish gray & green \\
\hline (33) & pyrethrin II & & & & & & \\
\hline
\end{tabular}

+ or color name, detected; \pm , detected slightly and color is unclear; and -, not detected. Developing solvents: A, $n$-hexane-toluene $(45: 55, \mathrm{v} / \mathrm{v}) ; \mathrm{B}, n$-hexane-chloroform $(60: 40, \mathrm{v} / \mathrm{v})$; and $\mathrm{C}, n$-hexane-diethylether $(50: 50, \mathrm{v} / \mathrm{v})$. Chromogenic reagents: a, UV light at $254 \mathrm{~nm} ; \mathrm{b}, 20 \%$ phosphomolybdic acid/ethanol solution; and c, $0.5 \% o$-tolidine/ethanol solution. 


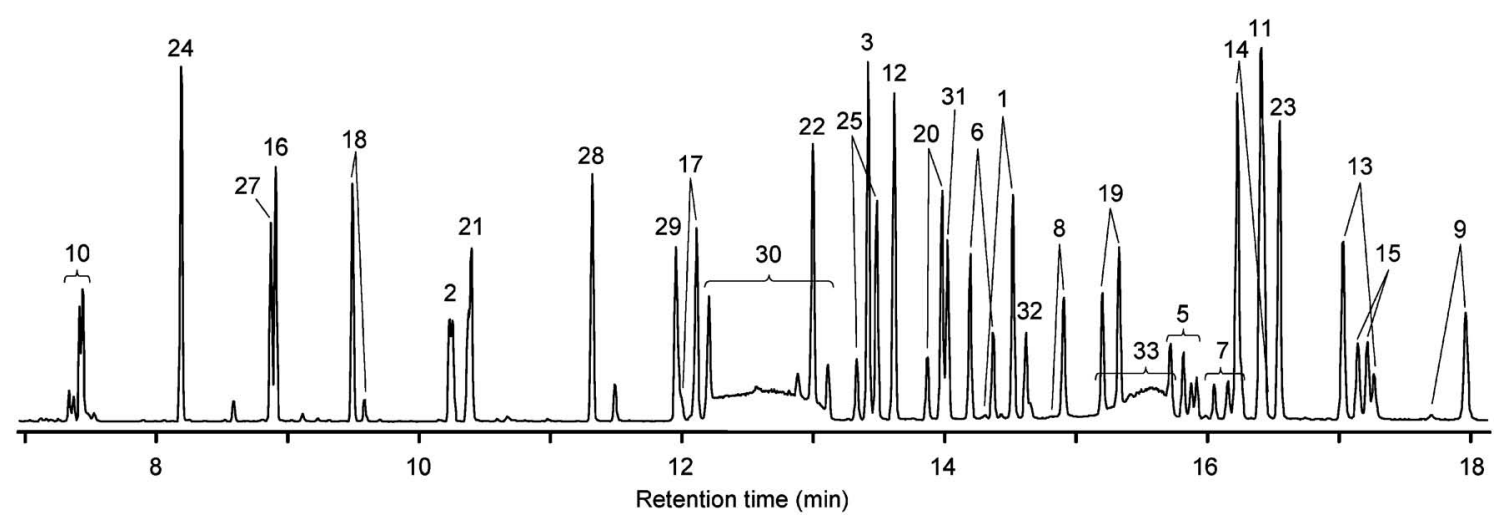

Fig. 2 GC/MS total ion chromatogram of 31 pyrethroids. The synthetic pyrethroids are $10 \mathrm{ng}$ each, and the natural pyrethrins are $100 \mathrm{ng}$ (a total of six compounds). For peak identification, see Table 3.

Table 2 Retention indices by GC/MS.

\begin{tabular}{|c|c|c|}
\hline No. & Compound & Retention index \\
\hline (1) & acrinathrin & 2587,2614 \\
\hline (2) & allethrin & 2072,2075 \\
\hline (3) & bifenthrin & 2472 \\
\hline (4) & cycloprothrin & - \\
\hline$(5)$ & cyfluthrin & $2776,2790,2800,2804$ \\
\hline (6) & cyhalothrin & 2572,2593 \\
\hline (7) & cypermethrin & $2823,2837,2844,2851$ \\
\hline (8) & cyphenothrin & 2653,2666 \\
\hline (9) & deltamethrin & 3031,3061 \\
\hline$(10)$ & empenthrin & $1696,1700,1707,1710$ \\
\hline (11) & ethofenprox & 2872 \\
\hline$(12)$ & fenpropathrin & 2496 \\
\hline$(13)$ & fenvalerate & 2951,2981 \\
\hline (14) & flucythrinate & 2846,2875 \\
\hline$(15)$ & fluvalinate & 2966, 2976 \\
\hline$(16)$ & furamethrin & 1906 \\
\hline$(17)$ & imiprothrin & 2287,2304 \\
\hline (18) & metofluthrin & 1981,1992 \\
\hline (19) & permethrin & 2704,2723 \\
\hline$(20)$ & phenothrin & 2529,2545 \\
\hline$(21)$ & prallethrin & 2089, 2091 \\
\hline$(22)$ & resmethrin & 2401,2417 \\
\hline$(23)$ & silafluofen & 2892 \\
\hline$(24)$ & tefluthrin & 1718 \\
\hline$(25)$ & tetramethrin & 2459,2479 \\
\hline$(26)$ & tralomethrin & 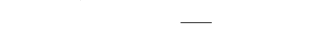 \\
\hline (27) & transfluthrin & 1903 \\
\hline$(28)$ & cinerin $\mathrm{I}$ & 2206 \\
\hline$(29)$ & jasmolin I & 2285 \\
\hline$(30)$ & pyrethrin $\mathrm{I}$ & $2310-2430^{*}, 2316,2433$ \\
\hline$(31)$ & cinerin $\mathbb{I}$ & 2549 \\
\hline$(32)$ & jasmolin $I I$ & 2627 \\
\hline$(33)$ & pyrethrin II & $2700-2780^{*}$ \\
\hline
\end{tabular}

-, not detected.

*, broad peak.
斉分離検出することが可能であった。検出下限は transfluthrin を除く全ての化合物で，フルスキャン モードで0.1〜3 ng, SIM モードで0.005〜0.2 ng で あり, transfluthrinについては，それぞれ $30 \mathrm{ng}, 2$ ng であった.

\section{4. 市販殺虫剤の分析}

市販のエアゾールタイプの殺虫剤 6 種類（石油系 溶剂タイプ 5 種類，水性タイプ 1 種類） と熱拡散式 の殺虫剂 2 種類（水性タイプおよび固形タイプ）に ついて，本法で分析を行った。これらの製品は， cyphenothrin, imiprothrin, metofluthrin, phenothrin, prallethrin, resmethrin, tetramethrinのうち, 1 3 種 類を含有するものである. 石油系溶剂タイプの製品 については，TLCによる直接分析，並びに，アセ トンで希釈した後， GC/MS および LC/MS 分析を 行った。水性タイプおよび固形タイプの製品につい ては，n-へキサンによる抽出液について TLC およ び GC/MS 分析を行ったほか、へキサン抽出液を 乾固した後，アセトンに再溶解し LC/MS 分析を行 った.

その結果， $\mathrm{GC} / \mathrm{MS}$ と LC/MS では，溶剤あるい はマトリックス成分の妨害無く上記ピレスロイド系 農薬の検出が可能であった，TLCでは，エアゾー 儿製品の場合，石油系溶剂タイプ，水性タイプ共に 含まれるテトラデカン等の炭化水素油成分が， 3 種 類の展開溶媒のいずれにおいても $\mathrm{Rf}$ 值 $0.6 \sim 0.8$ 付 近に巨大スポットとして出現し，同位置に出現する ピレスロイド系農薬のスポットの検出を妨害した。 
(1) acrinathrin

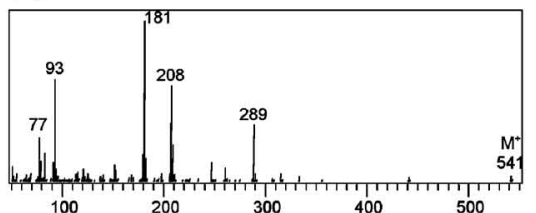

(5) cyfluthrin

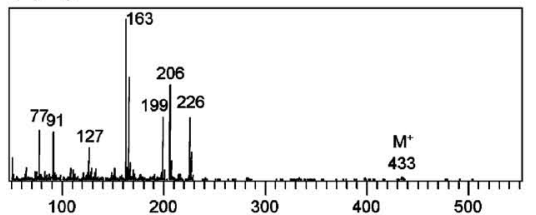

(8) cyphenothrin

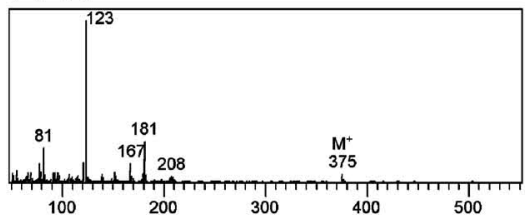

(11) ethofenprox

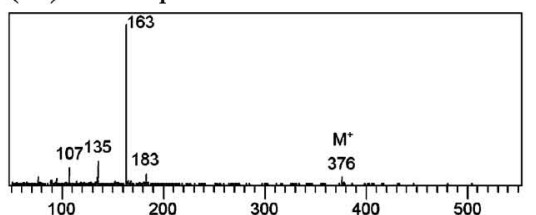

(14) flucythrinate

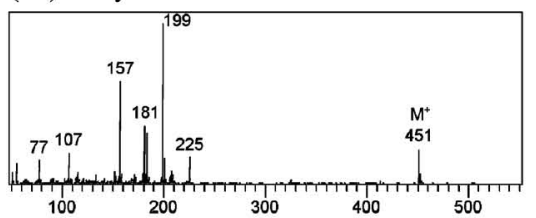

(17) imiprothrin

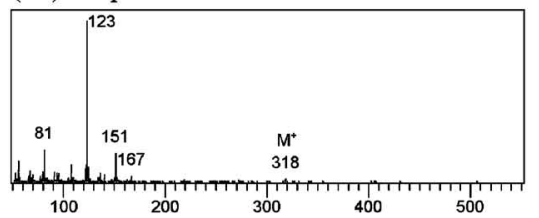

(20) phenothrin

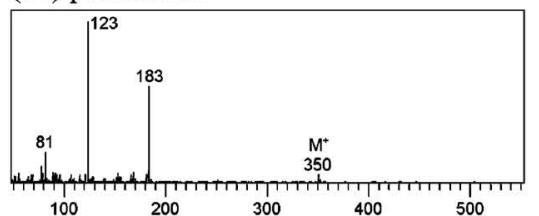

(23) silafluofen

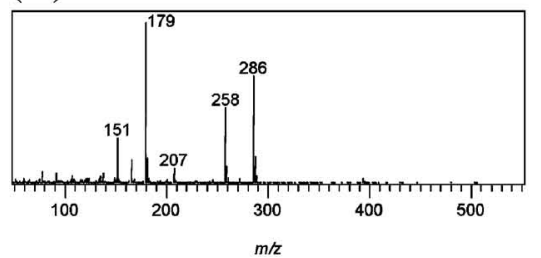

(2) allethrin

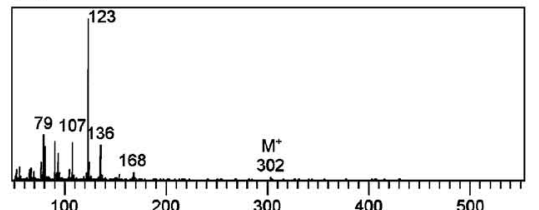

(6) cyhalothrin

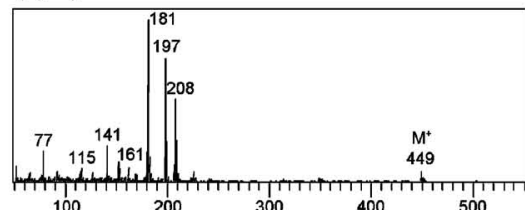

(9) deltamethrin

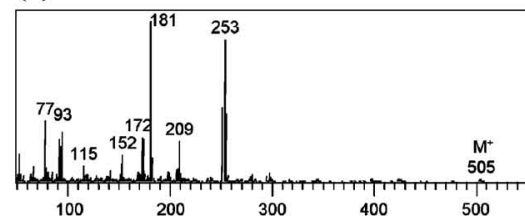

(12) fenpropathrin

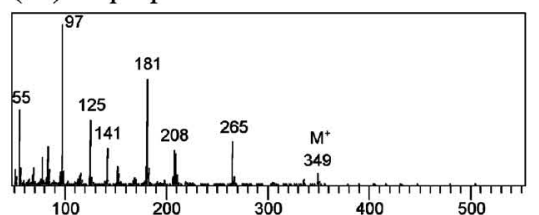

(15) fluvalinate

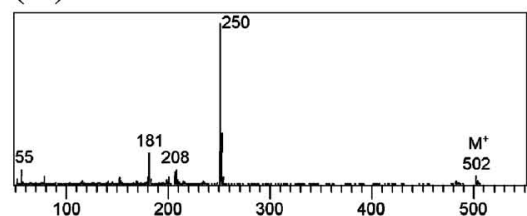

(18) metofluthrin

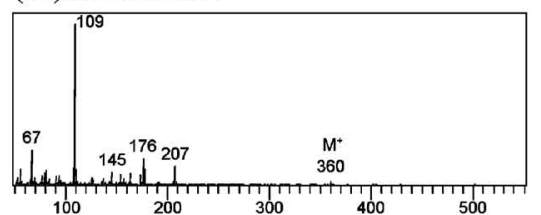

(21) prallethrin

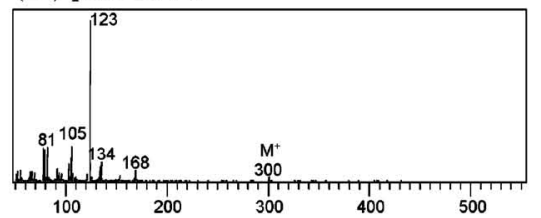

(24) tefluthrin

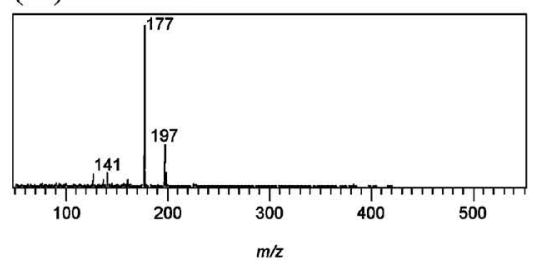

(3) bifenthrin

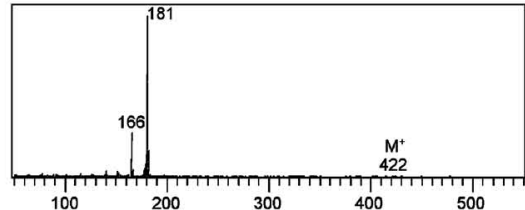

(7) cypermethrin

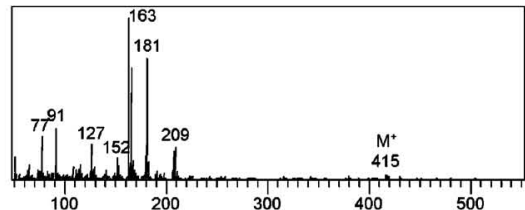

(10) empenthrin

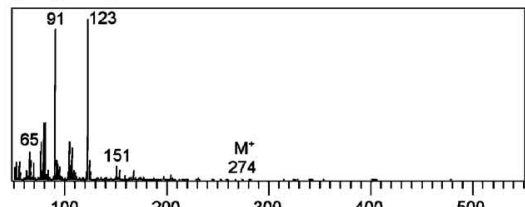

(13) fenvalerate

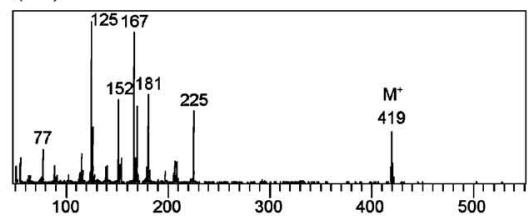

(16) furamethrin

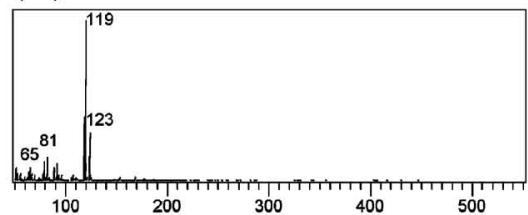

(19) permethrin

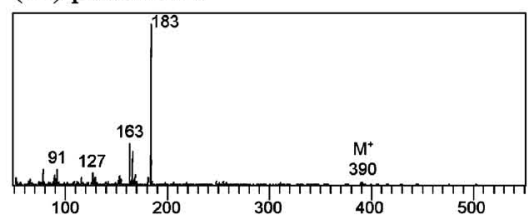

(22) resmethrin

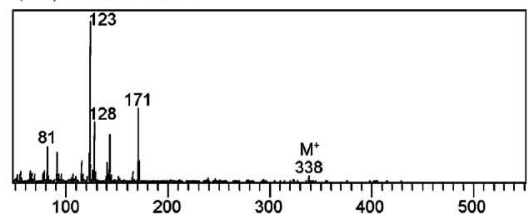

(25) tetramethrin

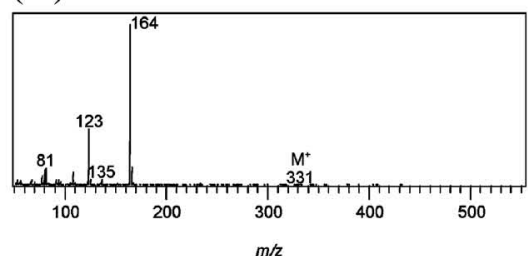

Fig. 3-(1) GC/MS spectra of 31 pyrethroids. 
(27) transfluthrin

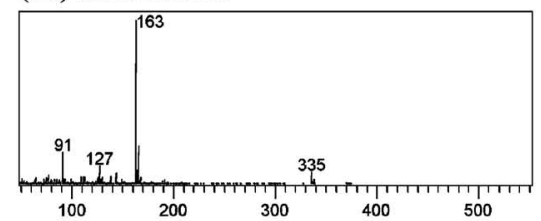

(30) pyrethrin I

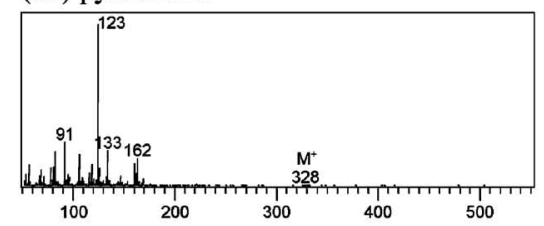

(33) pyrethrin II

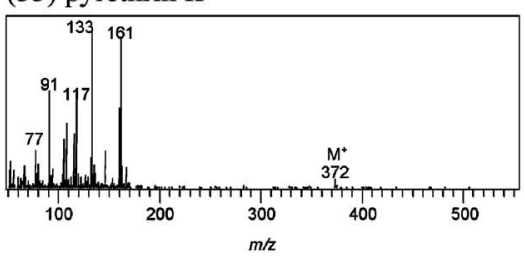

(28) cinerin I

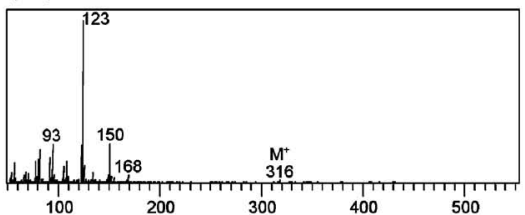

(31) cinerin II

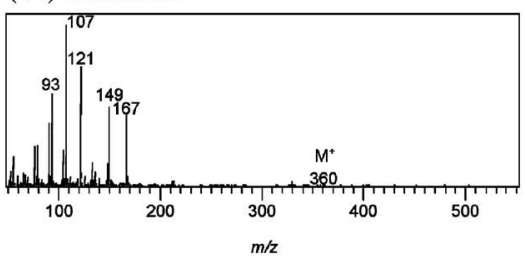

(29) jasmolin I

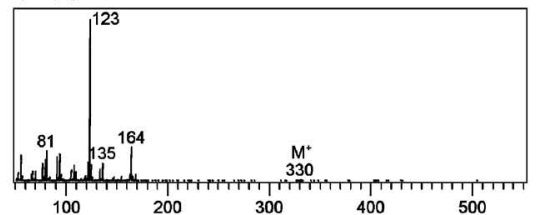

(32) jasmolin II

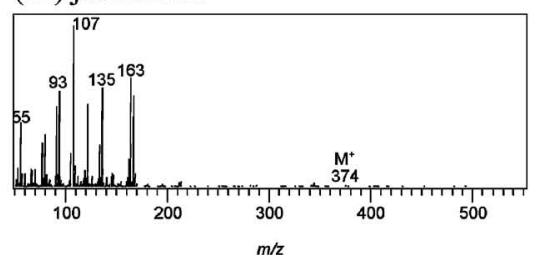

Fig. 3-(2) Continued.

炭化水素油成分と Rf 值が異なるスポットについて は問題なく検出が可能であった. したがって, 炭化 水素油を含有する製品の分析においては, 複数の展 開溶媒を用いて検討する等の注意が必要である.

\section{5. 添加飲食物の分析}

飲食物への混入事案を想定し, $\mu \mathrm{g} / \mathrm{ml} レ$ レ゙ル以上 の比較的高濃度のピレスロイド系農薬を添加した検 査試料を作製し，前処理法の検討を行ったところ， $n$-ヘキサンによる液液抽出により, 約 $80 \%$ 以上の回 収率が得られることが分かった。

そこで, tetramethrin 約 $2000 \mu \mathrm{g} / \mathrm{ml}$ および resmethrin 約 $200 \mu \mathrm{g} / \mathrm{ml}$ を含有する石油系溶剤エア ゾールタイプの市販殺虫剤を直接添加した飲食物を 検査試料として分析を行った. 緑茶飲料, オレンジ ジュース，コーラおよびコーヒー各 $5 \mathrm{ml}$ とレトル トカレー $5 \mathrm{~g}$ に殺虫剂 $0.1 \mathrm{ml}$ を添加し, 前処理の 後, TLC, GC/MS およびLC/MS で分析を行っ た。

TLC では, tetramethrin は展開溶媒 $\mathrm{A}$ および $\mathrm{B}$ ではほとんど移動しないことから, 展開溶媒 Cで 分析し，いずれの検査試料でも tetramethrin を妨害 無く検出できた。ただ， resmethrin は製品に含ま れる炭化水素油の成分の妨害を受けた. resmethrin
に関しては展開溶媒 A あるいは B を用いて分析す ることで，妨害無く検出が可能であった。

$\mathrm{GC} / \mathrm{MS}$ および LC/MS では，いずれの検査試料 からも tetramethrin と resmethrin が妨害無く検出 でき，マススペクトルの確認が可能であった． Fig. 5 に最も夾雑物成分が多く検出されたカレーの分析 例を示す．各検査試料について，あらかじめ標準試 料で作成した tetramethrin と resmethrin の検量線 を基に回收率を求めたところ，いずれの検査試料も GC/MS およびLC/MS ともに $70 \%$ 以上であった。

この他に, cyphenothrin, prallethrin, tetramethrin を含有するエアゾール殺虫剤についても添加実験を 行い，同様の結果を得ることができた.

以上, 本法はピレスロイド系農薬の一斉分析法と して有用であると考える.

\section{文 献}

1）日本薬学会編 : 衛生試験法 ·注解2005.pp. 459 -471 , 金原出版, 東京 (2005).

2) Columé, A., Cárdenas, S., Gallego, M. and Valcárcel, M.: Selective enrichment of 17 pyrethroids from lyophilised agricultural samples. $J$. Chromatogr. A., 912, 83-90 (2001). 


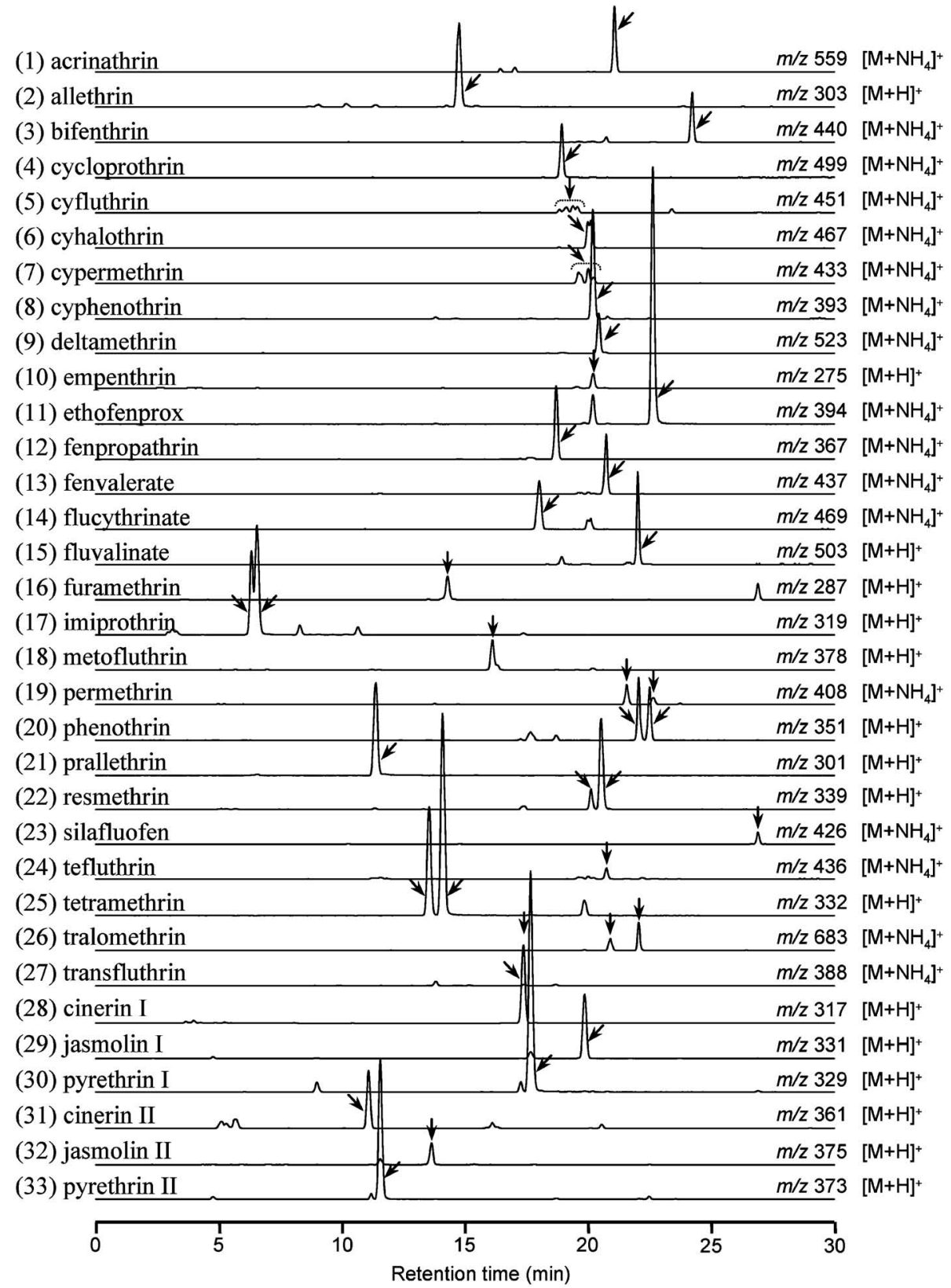

Fig. 4 LC/MS chromatograms of 33 pyrethroids. The synthetic pyrethroids are $36 \mathrm{ng}$ each, and the natural pyrethrins are $100 \mathrm{ng}$ (a total of six compounds).

3) Loper, B. L. and Anderson, K. A.: Determination of pyrethrin and pyrethroid pesticides in urine and water matrixes by liquid chromatography with diode array detection. J. AOAC Int., 86, 12361240 (2003).

4) Hu, X., Jianxin, Y., Zhigang, Y., Lansun, N., Yanfei, L., Peng, W., Jing, L., Xin, H., Xiaogang, C. and Yibin, Z.: Determination of multiclass pes- ticide residues in apple juice by gas chromatography-mass selective detection after extraction by matrix solid-phase dispersion. $J A O A C$ Int., 87, 972-985 (2004).

5) Tagami, T., Kajimura, K., Satsuki, Y., Nakamura, A., Okihashi, M., Kitagawa, Y., Takatori, S. and Kitagawa, M.: Simultaneous analysis of 10 pyrethroid pesticides in natural medicines 


\section{GC/MS}

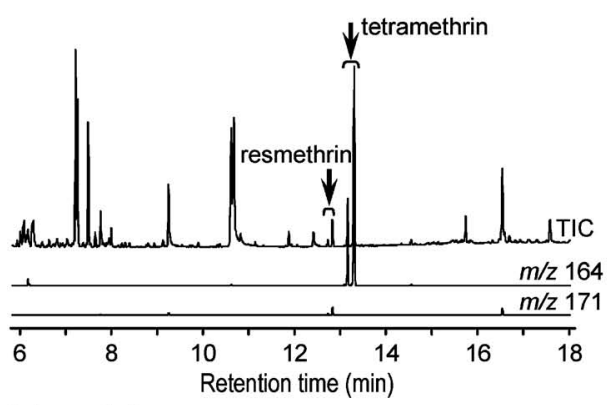

tetramethrin
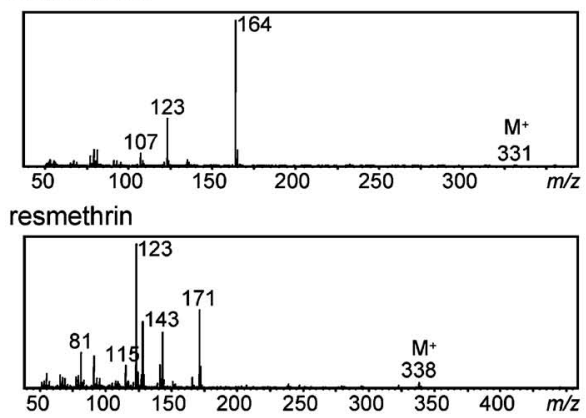

LC/MS

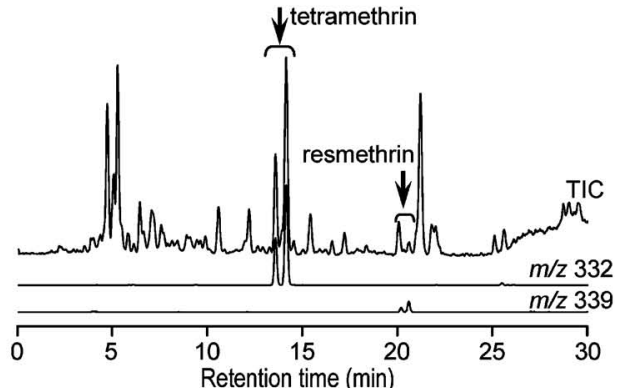

tetramethrin

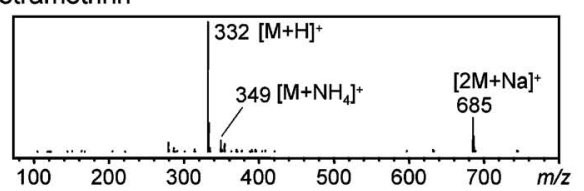

resmethrin

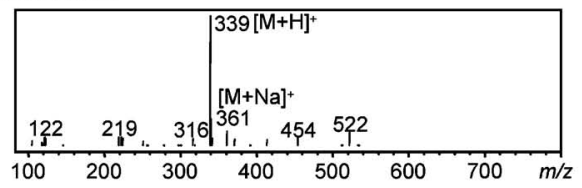

Fig. 5 Mass chromatograms and mass spectra of curry sample spiked with an aerosol spray insecticide analyzed by GC/MS and LC/MS.

by GC/MS with negative chemical ionization. Yakugaku Zasshi, 126, 991-995 (2006).

6) Shono, T., Ohsawa, K. and Casida, J. E.: Metabolism of trans and cis-permethrin, trans- and cis-cypermethrin, and decamethrin by microsomal enzymes. J. Agric. Food Chem., 27, 316-325 (1979).

7) Patil, V. B., Sevalkar, M. T. and Padalikar, S. V.: Thin-layer chromatographic detection of pyrethroid insecticides containing a nitrile group.
Analyst, 117, 75-76 (1992).

8) Valverde, A., Aguilera, A., Rodriguez, M. and Boulaid, M.: What are we determining using gas chromatographic multiresidue methods: tralomethrin or deltamethrin? J. Chromatogr. A., 943, 101-111 (2001).

9) Essig, K. and Zhao Z.: Method development and validation of a high-performance liquid chromatographic method for pyrethrum extract. J. Chromatogr. Sci., 39, 473-480 (2001). 